\title{
Eosinophils are cellular targets of the novel uteroplacental heparin-binding cytokine decidual/trophoblast prolactin-related protein
}

\author{
D Wang ${ }^{1}$, R Ishimura ${ }^{1}$, D S Walia ${ }^{1}$, H Müller ${ }^{1}$, G Dai ${ }^{1}$, \\ J S Hunt ${ }^{2}$, N A Lee ${ }^{3}$, J J Lee ${ }^{3}$ and $M$ J Soares ${ }^{1}$ \\ ${ }^{1}$ Department of Molecular and Integrative Physiology, University of Kansas Medical Center, Kansas City, Kansas 66160, USA \\ ${ }^{2}$ Department of Anatomy and Cell Biology, University of Kansas Medical Center, Kansas City, Kansas 66160, USA \\ ${ }^{3}$ Department of Biochemistry and Molecular Biology, Mayo Clinic Scottsdale, Scottsdale, Arizona 85259, USA \\ (Requests for offprints should be addressed to M J Soares; Email: msoares@kumc.edu) \\ ( $\mathrm{R}$ Ishimura is now at Laboratory of Cellular Biochemistry, Veterinary Medical Sciences, The University of Tokyo, 1-1-1 Yayoi, Bunkyo-ku, Tokyo 113, Japan) \\ ( $\mathrm{H}$ Müller is now at Department of Obstetrics and Gynecology, Universitats-Frauenklinik, Doberaner Str. 142, PF 1008 88, 18055 Rostock, Germany)
}

\begin{abstract}
The uterus and placenta of the mouse and rat produce a member of the prolactin (PRL) family referred to as decidual/trophoblast PRL-related protein (d/tPRP). This cytokine/hormone has been hypothesized to regulate decidual cell activities needed for the establishment and maintenance of gestation. An alkaline phosphatase (AP)tagging strategy was used to identify $\mathrm{d} / \mathrm{tPRP}$ target cells. $\mathrm{AP}-\mathrm{d} / \mathrm{tPRP}$ bound to virtually all cells and tissues to which it was exposed, consistent with our earlier evidence that $\mathrm{d} / \mathrm{tPRP}$ binds to heparin-containing molecules. Moreover, we found that co-incubation with heparin or pretreatment with heparitinase greatly decreased the binding of $\mathrm{AP}-\mathrm{d} / \mathrm{tPRP}$ to tissue sections. In addition, we observed that the $\mathrm{AP}-\mathrm{d} / \mathrm{tPRP}$ probe bound to the surface of Chinese hamster ovary (CHO) cells but not to heparan sulfate-deficient $\mathrm{CHO}-$ pgsD-677 cells. Potential unique non-heparin $d /$ tPRP binding sites within mouse and rat uteroplacental tissues were identified by consecutively
\end{abstract}

incubating sections with $\mathrm{AP}-\mathrm{d} / \mathrm{tPRP}$ followed by heparin. This strategy led to the identification of $d /$ tPRP target cells associated with the uterus and the labyrinth zone of the chorioallantoic placenta. Within the uterus, d/tPRP specifically bound to eosinophils. d/tPRP-binding and eosinophil peroxidase activity were co-localized and showed similar patterns of distribution during the estrous cycle, pregnancy, and following hormonal manipulation. $\mathrm{d} / \mathrm{tPRP}$ interactions with eosinophils were further demonstrated in the lung and intestine, with eosinophils isolated from the peritoneum, and in mice with generalized tissue eosinophilia. Collectively, these findings suggest that intercellular $\mathrm{d} / \mathrm{tPRP}$ targeting is mediated through associations with heparin-containing molecules which help direct $d /$ tPRP to specific interactions with eosinophils within the uterus and with the labyrinthine compartment of the chorioallantoic placenta.

Journal of Endocrinology (2000) 167, 15-28

\section{Introduction}

The establishment of pregnancy requires numerous concomitant maternal uterine changes, including those related to the vasculature and immune cells. Hemochorial placentation occurs in both primates and rodents, resulting in the establishment of a close connection between maternal and fetal tissues (Enders \& Welsh 1993). This close connection facilitates the exchange of nutrients and wastes at the expense of an increased risk of maternal immune system recognition of the genetically disparate embryo. Decidual and trophoblast cells, and their secretory products, likely provide the signaling system that coordinates the activities of the maternal uterine compartment.
Decidual cells arise from uterine stroma, forming intimate relationships with placental structures that facilitate the development of the embryo (DeFeo 1967, Bell 1983, Parr \& Parr 1989). Among the important functions of decidual cells are their hormone/cytokine producing capabilities. In the mouse and rat, decidual cell production of a hormone related to pituitary prolactin (PRL) is of particular interest. This hormone, referred to as decidual/trophoblast PRL-related protein (d/tPRP), has been implicated in directing early changes in the uteroplacental compartment required for the establishment of pregnancy (Roby et al. 1993, Rasmussen et al. 1996). $\mathrm{d} / \mathrm{tPRP}$ was originally isolated during a search for a putative decidual luteotropin (Roby et al. 1993). Although $\mathrm{d} / \mathrm{tPRP}$ exhibits significant structural similarities to PRL, 
it does not interact with PRL receptors and thus its putative luteotropic actions are suspect (Rasmussen et al. 1996). $d /$ tPRP is predominantly expressed by decidual cells during the first half of pregnancy and subsequently by spongiotrophoblast and trophoblast giant cells of the chorioallantoic placenta during the second half of pregnancy (Roby et al. 1993, Gu et al. 1994, Lin et al. 1997, Orwig et al. 1997a,b; Rasmussen et al. 1997). Once secreted from its cellular source, $\mathrm{d} / \mathrm{tPRP}$ readily associates with heparin-containing molecules and accumulates in the extracellular matrix (Rasmussen et al. 1996). Thus, $\mathrm{d} / \mathrm{tPRP}$ is strategically positioned to interact with various populations of cells traversing the uteroplacental compartment (i.e. endothelial, immune and trophoblast cells).

The purpose of this investigation was to specifically identify cellular targets for $\mathrm{d} / \mathrm{tPRP}$. We have utilized an alkaline phosphatase (AP) tagging strategy that has been effectively used for identifying targets for other members of the PRL family (Müller et al. 1998, 1999). We show that $\mathrm{AP}-\mathrm{d} / \mathrm{tPRP}$ binds specifically to cells within the uterus and in the developing chorioallantoic placenta, including infiltrating eosinophils.

Eosinophils contribute actively to inflammatory responses through their secretion of a variety of chemical mediators (Gleich et al. 1993, Venge 1993, Weller 1993, Hirai et al. 1997, Rothenberg 1998, Giembycz \& Lindsay 1999). These cells are actively recruited to sites of allergic responses (Kay et al. 1997), tumors (Tepper et al. 1992) and parasite infestation (Pearlman 1997). Eosinophil dynamics are precisely controlled within the uterus by the hormonal milieu, and exhibit dramatic fluctuations during the reproductive cycle (Rytomaa 1960, Bassett 1962, Ross \& Klebanoff 1966, McMaster et al. 1992, Jeziorska et al. 1995). For example, estrogen stimulates the infiltration of eosinophils into the uterus, whereas uterine exposure to progesterone is associated with eosinophil exit and death (Bjersing \& Borglin 1964, King et al. 1981, Tchernitchin 1983, Lee et al. 1989, Howe et al. 1990). The present study suggests that since $d / t P R P$ specifically interacts with eosinophils, this cytokine is a candidate mediator of the anti-inflammatory actions of progesterone during gestation.

\section{Materials and Methods}

\section{Reagents}

Supplies for polyacrylamide gel electrophoresis were purchased from Bio-Rad (Hercules, CA, USA). All restriction enzymes, polymerases, and DNA ligase were purchased from New England Biolabs (Beverly, MA, USA). Transformation competent DH $\alpha 5$ bacterial cells, $P f u$ polymerase were acquired from Stratagene (La Jolla, CA, USA). DNA extraction kits were purchased from Qiagen (Chatsworth, CA, USA). FuGene 6 transfection reagent was obtained from Boehringer Mannheim (Indianapolis, IN, USA). T7 DNA sequencing kits were acquired from United States Biochemical (Cleveland, $\mathrm{OH}$, USA). The $\mathrm{pCMV/SEAP} \mathrm{vector} \mathrm{was} \mathrm{acquired} \mathrm{from}$ Tropix Inc. (Bedford, MA, USA). The pECE/long PRL receptor expression vector was a generous gift from Dr Paul Kelly (INSERM, Paris, France). All cell lines were obtained from the American Type Culture Collection (ATCC, Rockville, MD, USA). Rat antimouse macrophage antibody, F4/80, was obtained from Dr Stephen Russell of the University of Kansas Medical Center (Kansas City, KS, USA). Antibodies to rat major basic protein were obtained from $\operatorname{Dr} M \mathrm{~J}$ Dembele-Duchesne (INSERM, Montpellier, France). Mouse anti-rat macrophage antibodies, ED1 and ED2, were obtained from Harlan Bioproducts (Indianapolis, IN, USA). Avidin-biotin-immunoperoxidase kits were purchased from Zymed Laboratories (South San Francisco, CA, USA). Reagents for the detection of immune complexes by enhanced chemiluminescence were acquired from Amersham Corp. (Arlington Heights, IL, USA). Unless otherwise noted, all other chemicals and reagents were purchased from Sigma (St Louis, MO, USA).

\section{Animals and tissue preparation}

Holtzman rats and CD-1 mice were obtained from Harlan Sprague-Dawley (Indianapolis, IN, USA). The IL-5 transgenic mouse line (NJ-1638) was established and propagated as previously described (Lee et al. 1997b). Timed pregnancies, pseudopregnancies and tissue dissections were performed as previously described (Soares et al. 1983, Soares 1987, Roby et al. 1993, Orwig et al. 1997b). The presence of a copulatory plug was designated day 1 of pregnancy. Deciduomal responses were induced in pseudopregnant mice by injection of $50 \mu \mathrm{l}$ sesame oil per uterine horn on day 4 of pseudopregnancy (Orwig et al. 1997b). In some experiments, prepubertal rats (day 20 postnatal) were subcutaneously injected daily for 3 days with estradiol valerate $(100 \mu \mathrm{g} / 100 \mu \mathrm{l}$; Bristol-Myers Squibb, Princeton, NJ, USA) or vehicle (sesame oil). Twenty-four hours following the last injection, rats were killed, uterine tissues dissected, and frozen for subsequent analysis. In all experiments, at least three different tissue samples were examined from a minimum of three different animals. Protocols for the care and use of animals were approved by the University of Kansas Animal Care and Use Committee.

\section{Cell culture}

Human embryonic kidney (HEK) 293 cells were used as a host for the expression of the AP- $\mathrm{d} / \mathrm{tPRP}$ fusion protein. HEK 293 cells were routinely maintained in minimum essential medium (MEM) supplemented with $20 \mathrm{mM}$ 
HEPES, 100 units $/ \mathrm{ml}$ penicillin, $100 \mu \mathrm{g} / \mathrm{ml}$ streptomycin and $10 \%$ fetal bovine serum (FBS). CHO cells, heparan sulfate-deficient CHO-pgsD-677 cells (Lidholt et al. 1992), and d/tPRP-expressing CHO cells (Rasmussen et al. 1996) were maintained in Dulbecco's MEM/MCDB 302 culture medium containing 100 units $/ \mathrm{ml}$ penicillin, $100 \mu \mathrm{g} / \mathrm{ml}$ streptomycin and 10\% FBS. All cells were cultured in an atmosphere of $5 \% \mathrm{CO}_{2}-95 \%$ air at $37^{\circ} \mathrm{C}$ in a humidified incubator.

\section{Generation and characterization of the $A P-d / t P R P$ fusion protein}

A fusion protein consisting of a modified human placental AP (PLAP) and rat d/tPRP was generated and used to monitor $d / t P R P$ target cell interactions. Procedures for generating the fusion protein were similar to those previously reported for the generation of an AP-placental lactogen-I (AP-PL-I) fusion protein (Müller et al. 1998). A vector containing ampicillin and neomycin resistance genes and a secreted version of PLAP (SEAP; Berger et al. 1988) situated downstream of a CMV promoter (pCMV/SEAP) was commercially obtained (Tropix). A nucleotide region representing the mature rat $\mathrm{d} / \mathrm{tPRP}$ protein was then amplified and ligated into the pCMV/SEAP vector. Ligation with the $\mathrm{d} / \mathrm{tPRP}$ insert resulted in a CMV promoter driven vector containing the ligated $\mathrm{cDNAs}$ encoding a SEAP-d/tPRP fusion protein $(\mathrm{AP}-\mathrm{d} / \mathrm{tPRP})$. DNA sequencing of the insert was performed to verify the accuracy of the PCR amplification. After linearization, the AP-d/tPRP construct was electroporated into HEK 293 cells. Following a 2-week selection

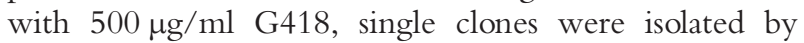
limiting dilution and screened for secreted heat stable AP activity. An unmodified pCMV/SEAP vector (AP) was similarly transfected, selected and served as a negative control. After the cells reached confluency, the culture medium was changed to serum-free MEM+ HEPES, further conditioned for $72 \mathrm{~h}$, collected and clarified by centrifugation, and stored at $-20^{\circ} \mathrm{C}$ until used. AP activity was measured from conditioned medium via a colorimetric assay (Müller et al. 1998). Western blot analysis for $\mathrm{d} / \mathrm{tPRP}$ was performed as previously described (Rasmussen et al. 1996). AP-d/tPRP preparations were isolated from conditioned medium using immunoprecipitation with monoclonal antibodies to AP conjugated to agarose. PRL-like biological activities were assessed through the use of the rat $\mathrm{Nb} 2$ lymphoma cell proliferation assay (Tanaka et al. 1980, Deb et al. 1993) and through incubation with $\mathrm{CHO}$ cells transiently transfected with the long form of the rat PRL receptor ( $\mathrm{pECE} /$ long, Ali et al. 1992).

\section{Analysis of AP-d/tPRP binding to tissues and cells}

Tissues were frozen in dry ice-cooled heptane and stored at $-70{ }^{\circ} \mathrm{C}$ until tissue sections $(8-10 \mu \mathrm{m})$ were prepared with the aid of a cryostat. Sections were mounted onto glass slides, washed in a modified Hank's balanced salt solution (HBHA; containing $20 \mathrm{mM}$ HEPES, $0.5 \mathrm{mg} / \mathrm{ml}$ BSA and $0 \cdot 1 \% \mathrm{NaN}_{3}$ ) and incubated with $\mathrm{AP}, \mathrm{AP}-\mathrm{d} /$ tPRP, or $A P-d / t P R P+$ excess recombinant rat $d / t P R P$ for 75 min. Recombinant rat $\mathrm{d} / \mathrm{tPRP}$ was generated in $\mathrm{CHO}$ cells and purified as previously described (Rasmussen et al. 1996). Following incubation, the sections were washed with HBHA supplemented with $0 \cdot 1 \%$ Tween 20 and fixed for $2 \mathrm{~min}$ in $20 \mathrm{mM}$ HEPES buffer containing acetone $(60 \%)$ and formaldehyde (3\%). The fixed sections were washed, heated at $65^{\circ} \mathrm{C}$ for $30 \mathrm{~min}$ to inactivate endogenous tissue AP activity, and then processed for detection of the heat stable AP activity associated with the fusion proteins (Müller et al. 1998). For in situ AP detection 5-bromo-4-chloroindoxyl phosphate substrate and Nitroblue Tetrazolium were used. In experiments designed to co-localize $\mathrm{AP}-\mathrm{d} / \mathrm{tPRP}$-binding and F4/80-immunoreactive cells, AP-fusion protein binding was assessed with a mouse monoclonal antibody to human PLAP (clone 8B6) and FITC-labeled goat anti-mouse IgG antibodies. Distinction of $\mathrm{AP}-\mathrm{d} / \mathrm{tPRP}$ binding to heparincontaining molecules from other potential interactions was achieved by treating tissue sections with heparin $(250 \mu \mathrm{g} / \mathrm{ml}$ to $10 \mathrm{mg} / \mathrm{ml})$ for $5 \mathrm{~min}$ following the HBHA and $0 \cdot 1 \%$ Tween 20 washes. AP- $\mathrm{d} / \mathrm{tPRP}$ binding to tissue sections was also evaluated following preincubation with heparitinase ( 5 units $/ \mathrm{ml}$ ) at $37^{\circ} \mathrm{C}$ for $1 \mathrm{~h}$. The specificity of binding was further assessed by incubation with the AP control or by the addition of recombinant $d / t P R P$. $\mathrm{AP}-\mathrm{d} / \mathrm{tPRP}$ binding was also evaluated in various leukocytic cell populations (including eosinophils and macrophages) isolated from the rat peritoneum. Finally, $\mathrm{AP}-\mathrm{d} / \mathrm{tPRP}$ binding was assessed in $\mathrm{CHO}$ cells transiently transfected with an expression vector containing the long form of the rat PRL receptor (pECE/long, Ali et al. 1992) using FusGene 6 according to the manufacturer's instructions. The AP-PL-I fusion protein (Müller et al. 1998) was used as a positive control for binding to the rat PRL receptor.

\section{Isolation of rat peritoneal cells}

Peritoneal serosal cells from rats were collected by lavage of the peritoneal cavity with MEM containing $15 \mathrm{mM}$ HEPES, 10\% FBS and heparin (50 $\mu \mathrm{g} / \mathrm{ml}$; HMEM) as previously described (Dileepan et al. 1993). After gentle massage for $1 \mathrm{~min}$, the peritoneal fluid was aspirated and the cells washed twice with HMEM. Macrophages and eosinophil fractions were isolated based on the procedure of MacKenzie et al. (1981). Briefly, peritoneal cells were cultured for $2 \mathrm{~h}$ in $75 \mathrm{~cm}^{2}$ plastic tissue culture flasks. Of the adherent cells $>95 \%$ were macrophages. Nonadherent cells were collected, washed and resuspended in HMEM at a concentration of $10^{7}$ cells $/ \mathrm{ml}$. Cells were further fractionated over a metrizamide gradient. 
Metrizamide was made up to $18.5 \%$ and $22.5 \%(\mathrm{w} / \mathrm{v}$ ) solution in HBSS (Hank's balanced salt solution). Two milliliters of the $22 \cdot 5 \%$ metrizamide solution were overlaid with $2 \mathrm{ml}$ of the $18.5 \%$ solution in a $15 \mathrm{ml}$ centrifuge tube. One milliliter of the $1 \times 10^{7}$ cells $/ \mathrm{ml}$ suspension of non-adherent cells was added and the tube centrifuged at room temperature for $15 \mathrm{~min}$ at $400 \mathrm{~g}$. Eosinophils were collected at the $18.5 \%-22.5 \%$ metrizamide interface at a purity of $85-90 \%$.

\section{Immunocytochemical and histochemical analyses}

d/tPRP protein expression was monitored by immunocytochemistry with antibodies to rat d/tPRP (Rasmussen et al. 1996). Immunocytochemical identification of rat and mouse eosinophils utilized rabbit polyclonal antibodies to mouse and rat major basic protein respectively (Dembele-Duchesne et al. 1991, Lee et al. 1997a). Eosinophils were histochemically identified by the presence of cyanide-resistant $(8 \mathrm{mM} \mathrm{NaCN})$ peroxidase activity as previously described (Horton et al. 1996). For identification of cells of the mouse macrophages/ eosinophil lineage a rat monoclonal antibody referred to as F4/80 was used (Austyn \& Gordon 1981, McGarry \& Stewart 1991), whereas rat macrophages were identified with mouse monoclonal antibodies referred to as ED1 and ED2 (Dijkstra et al. 1985). Immunocytochemistry was performed with streptavidin-biotin-immunoperoxidase kits using 3-amino-9-ethyl carbazole as a substrate. Control sections were incubated with non-immune serum or non-immune $\operatorname{IgG}$.

\section{Results}

Generation and characterization of the $A P-d / t P R P$ fusion protein

We generated and characterized an $\mathrm{AP}-\mathrm{d} / \mathrm{tPRP}$ fusion protein by in-frame insertion of the cDNA sequence of mature rat $\mathrm{d} / \mathrm{tPRP}$ downstream from the SEAP coding sequence within the $\mathrm{pCMV} / \mathrm{SEAP}$ vector (Tropix Inc.). The AP $-\mathrm{d} / \mathrm{tPRP}$ construct and an unmodified AP control vector were transfected via electroporation into HEK 293 cells. The presence of AP activity in conditioned medium from transfected and non-transfected cells was evaluated using a colorimetric assay. Western blot analysis showed that $\mathrm{d} / \mathrm{tPRP}$ antibodies recognized an $\mathrm{AP}-\mathrm{d} / \mathrm{tPRP}$ protein species approximating $110 \mathrm{kDa}$ and native $\mathrm{d} / \mathrm{tPRP}$ protein species of $29 \mathrm{kDa}$ (Fig. 1). The $110 \mathrm{kDa} M_{\mathrm{r}}$ of the $\mathrm{AP}-\mathrm{d} / \mathrm{tPRP}$ fusion protein was consistent with the predicted $M_{\mathrm{r}}$ of its AP and d/tPRP components. The AP-only control preparation was not recognized by the $\mathrm{d} / \mathrm{tPRP}$ antibodies.

The AP- $\mathrm{d} / \mathrm{tPRP}$ fusion protein was evaluated for its ability to interact with heparin-containing cells and the

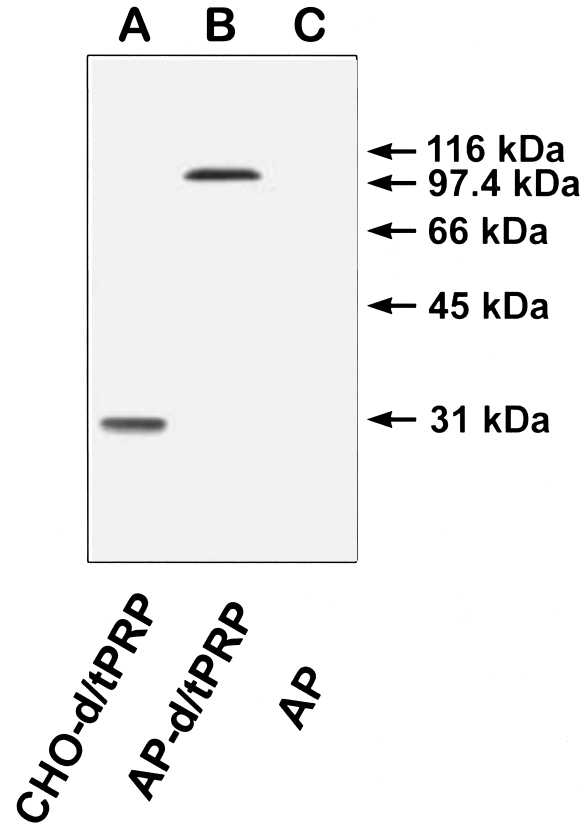

Figure 1 Characterization of the AP-d/tPRP expression vector. A fusion protein consisting of a modified human placental alkaline phosphatase (AP) and rat d/tPRP was generated and used to monitor $\mathrm{d} / \mathrm{tPRP}$ target cell interactions. AP-d/tPRP was initially characterized by Western blot analysis. Samples were separated by polyacrylamide gel electrophoresis in $7 \cdot 5 \%$ gels under reducing conditions and were electrophoretically transferred to nitrocellulose. Polyclonal antibodies generated against d/tPRP were used as probes. Immune complexes were detected using the enhanced chemiluminescence system. Lane $A$, recombinant d/tPRP; lane B, AP-d/tPRP preparations from HEK 293 cells stably transfected with the $\mathrm{pCMV} \mathrm{AP-d/tPRP}$ expression vector; lane $\mathrm{C}$, control conditioned medium from AP-transfected HEK 293 cells. Please note that the AP-d/tPRP fusion protein migrated at a $M_{\mathrm{r}}$ approximating $110 \mathrm{kDa}$, while native $\mathrm{d} / \mathrm{tPRP}$ migrated at a $M_{\mathrm{r}}$ of 29 .

PRL receptor. The $\mathrm{AP}-\mathrm{d} / \mathrm{tPRP}$ fusion protein bound readily to heparan sulfate-containing wild-type $\mathrm{CHO}$ cells but not to heparan sulfate-deficient CHO-pgsD-677 cells (Fig. 2, top panel). Moreover, AP-d/tPRP failed to bind heparan sulfate-deficient $\mathrm{CHO}$ cells transiently transfected with the long form of the rat PRL receptor (Fig. 2, bottom panel). In contrast, AP-PL-I, a known ligand of the PRL receptor, effectively bound to the PRL receptor transfected cells (Fig. 2, bottom panel). Neither d/tPRP or the AP $-\mathrm{d} / \mathrm{tPRP}$ fusion protein stimulated the proliferation of the PRL-responsive Nb2 lymphoma cells (data not shown). Collectively, these observations are consistent with earlier reports that $\mathrm{d} / \mathrm{tPRP}$ interacts with heparincontaining molecules and does not activate the PRL receptor signaling pathway (Rasmussen et al. 1996).

Identification of $d / t P R P$ targets within the uterus

Heparin-dependent interactions $\mathrm{AP}-\mathrm{d} / \mathrm{tPRP}$ was used as a histo-specific marker to identify potential targets 


\title{
Normal CHO cells
}

\section{Heparin deficient CHO cells}

AP-d/tPRP
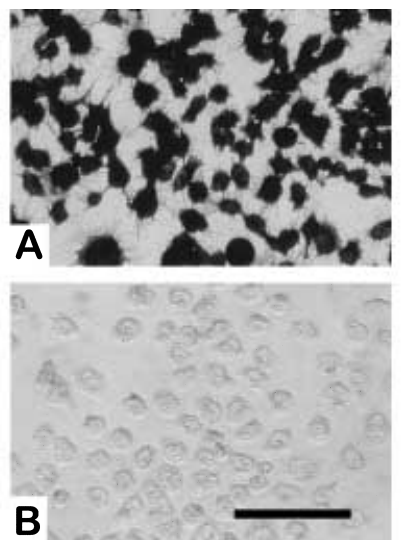
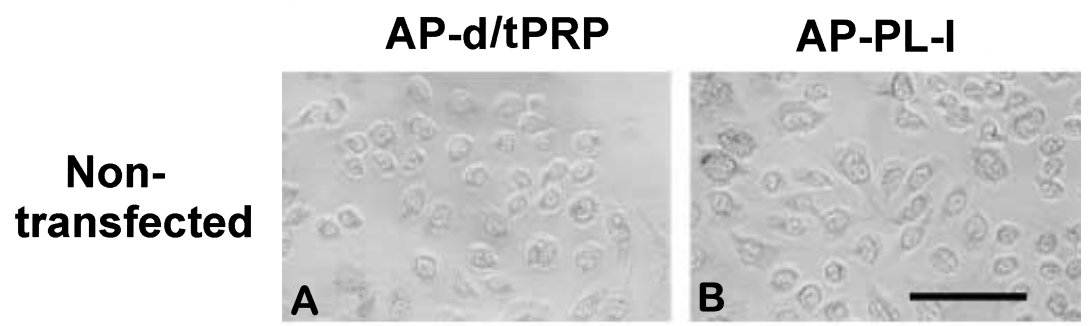

PRLR
transfected
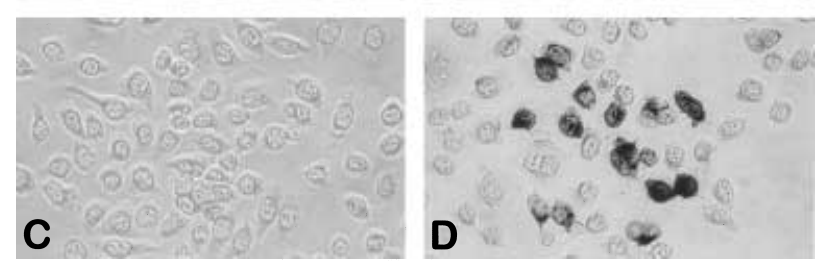

Heparin deficient $\mathrm{CHO}$ cells

\begin{abstract}
Figure $2 \mathrm{AP}-\mathrm{d} / \mathrm{tPRP}$ binding to heparin-containing molecules and lack of binding to the PRL receptor. (Top panel) Wild-type $\mathrm{CHO}$ cells (A) and heparan sulfate-deficient CHO-pgsD-677 cells (B) were probed with the AP-d/tPRP fusion protein. Please note the extensive binding of $\mathrm{AP}-\mathrm{d} / \mathrm{tPRP}$ to the wild-type $\mathrm{CHO}$ heparan sulfate-containing cells and the relative absence of $d / t P R P$ binding to the heparan sulfate-deficient $\mathrm{CHO}$ cells. The length of the bar in B represents $200 \mu \mathrm{m}$. (Bottom panel) Heparan sulfate-deficient CHO-pgsD-677 cells were transiently transfected with the long form of the rat PRL receptor ( $\mathrm{pECE} /$ long) and probed with the $\mathrm{AP}-\mathrm{d} / \mathrm{tPRP}(\mathrm{A}$ and $\mathrm{C})$ or $\mathrm{AP}-\mathrm{PL}-\mathrm{I}(\mathrm{B}$ and $\mathrm{D})$ fusion proteins. Please note that $\mathrm{AP}-\mathrm{d} / \mathrm{tPRP}$ failed to bind heparan sulfate-deficient $\mathrm{CHO}$ cells transiently transfected with the PRL receptor. In contrast, AP-PL-I bound to CHO cells transfected with the PRL receptor (PRLR). The length of the bar in B represents $200 \mu \mathrm{m}$.
\end{abstract}

in mouse and rat uteroplacental tissues during various stages of gestation. The $\mathrm{AP}-\mathrm{d} / \mathrm{tPRP}$ probe bound to virtually all components of the uterus. This widespread interaction of $\mathrm{AP}-\mathrm{d} / \mathrm{tPRP}$ with uteroplacental compartments was shown to be dependent on heparin-containing molecules since pretreatment of tissue sections with heparitinase greatly decreased $\mathrm{AP}-\mathrm{d} / \mathrm{tPRP}$ binding
(Fig. 3) as did preincubation of AP-d/tPRP with heparin (data not shown). A population of non-heparin binding sites was identified by consecutively incubating tissue sections with $\mathrm{AP}-\mathrm{d} / \mathrm{tPRP}$ followed by excess heparin $(250 \mu \mathrm{g} / \mathrm{ml}$ to $10 \mathrm{mg} / \mathrm{ml})$. This strategy led to the identification of discrete $\mathrm{d} / \mathrm{tPRP}$ target cells within the endometrium and myometrium of the non-pregnant rat 

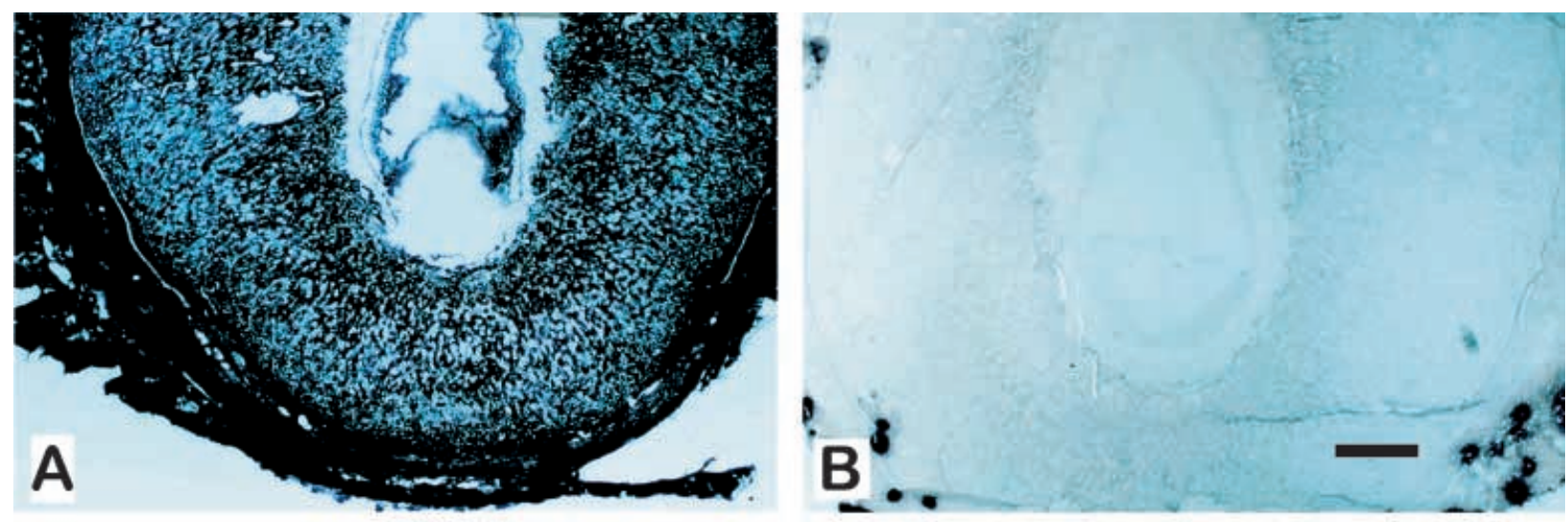

\section{$(-) \quad$ Heparitinase}

$(+)$

Figure $3 \mathrm{AP}-\mathrm{d} / \mathrm{tPRP}$ binding to heparin-containing molecules in the mouse uterus. AP-d/tPRP binding was detected by AP histochemistry. (A) Uterine tissue section from day 8 of pregnancy probed with AP-d/tPRP; (B) uterine tissue section from day 8 of pregnancy pretreated with heparitinase and probed with AP-d/tPRP. Please note that pretreatment of the tissue section with heparitinase significantly decreased AP-d/tPRP binding. The length of the bar in B represents $300 \mu \mathrm{m}$.

uterus (Fig. 4). Specificity of the $\mathrm{d} / \mathrm{tPRP}$ interaction with uterine cells was further demonstrated by use of an AP control probe, which showed no detectable binding to uterine tissue sections (Fig. 4) and by competition assays demonstrating that excess recombinant $\mathrm{d} / \mathrm{tPRP}$ attenuated the binding of $\mathrm{AP}-\mathrm{d} / \mathrm{tPRP}$ to the uterine cells (Fig. 4).

\section{Distribution of $d / t P R P$ binding within the uterus} The distribution of AP- $\mathrm{d} / \mathrm{tPRP}$ target cells within mouse and rat uteri was similar to the distribution of leukocytes, especially macrophages and eosinophils within the uterus (Bassett 1962, Ross \& Klebanoff 1966, Tachi \& Tachi 1986, 1989, Redline et al. 1989, McMaster et al.
1992, King et al. 1981, Stewart \& Mitchell 1991, 1992, Yelavarthi et al. 1991, Brandon 1993, 1995, Kaushic et al. 1998). In order to clarify this relationship, d/tPRP binding was compared with the distribution of the F4/80 antigen (a macrophage/eosinophil marker; Austyn \& Gordon 1981, McGarry \& Stewart 1991) and eosinophils via monitoring of eosinophil peroxidase histochemistry (King et al. 1981, Horton et al. 1996). In some cases, eosinophils were localized using immunocytochemistry for major basic protein-1, an eosinophil-specific granule protein (Dembele-Duchesne et al. 1991, Lee et al. 1997a). While the distributions of $\mathrm{d} / \mathrm{tPRP}$ binding and F4/80 immunoreactivity were only roughly similar, the locations of
AP

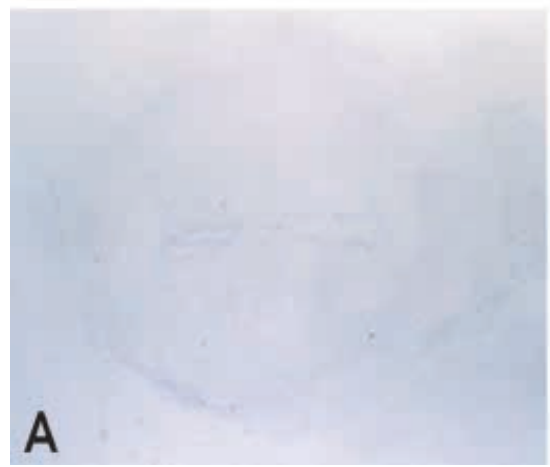

AP-d/tPRP

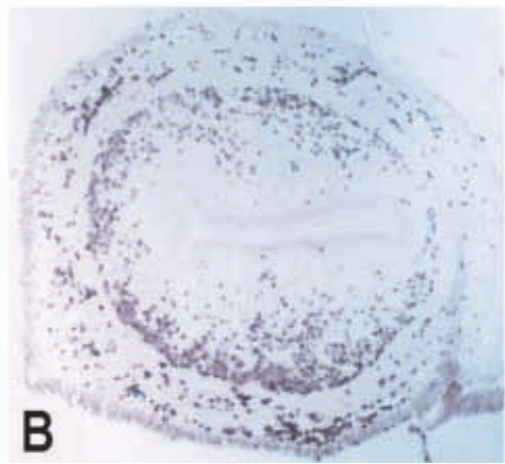

AP-d/tPRP + d/tPRP

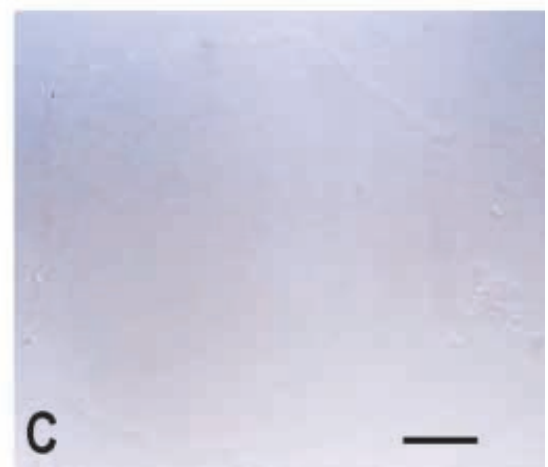

Figure $4 \mathrm{AP}-\mathrm{d} / \mathrm{tPRP}$ target cells in the uterus of the non-pregnant rat. Separation of AP- $d /$ tPRP binding to heparan-containing molecules from other potential interactions was achieved by post-AP-d/tPRP incubation of tissue sections with heparin $(250 \mu \mathrm{g} / \mathrm{ml})$. AP-d/tPRP binding was detected by AP histochemistry. (A) Rat uterine tissue section probed with AP control; (B) rat uterine tissue section probed with $\mathrm{AP}-\mathrm{d} / \mathrm{tPRP}$ fusion protein; $(\mathrm{C})$ rat uterine tissue section probed with $\mathrm{AP}-\mathrm{d} / \mathrm{tPRP}$ fusion protein excess recombinant $\mathrm{d} / \mathrm{tPRP}$. Please note that $A P-d / t P R P$ binding to rat uterine tissue sections is specific. The length of the bar in $C$ represents $250 \mu \mathrm{m}$. 
AP-d/tPRP

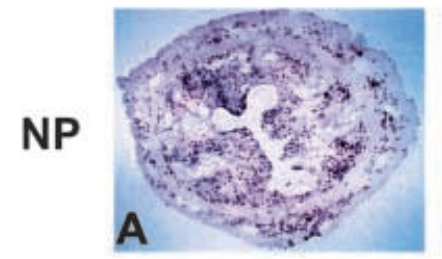

PsD4
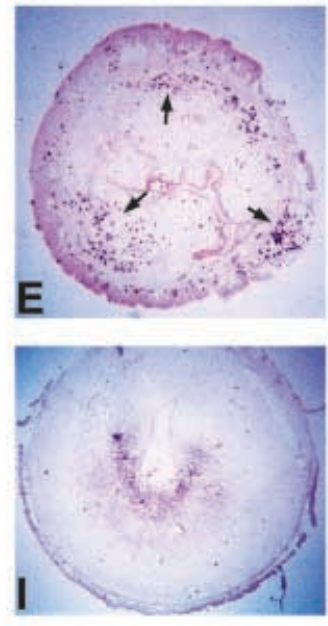

PsD7

PrD7
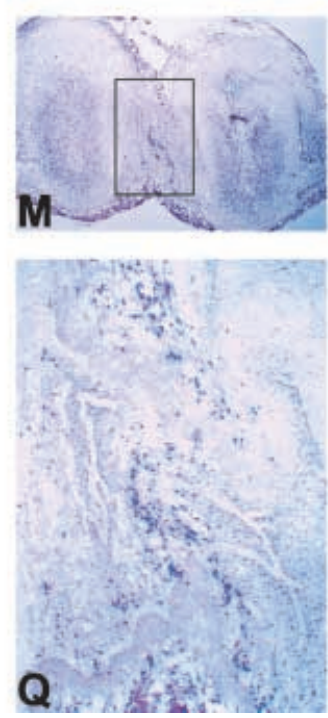

EPO
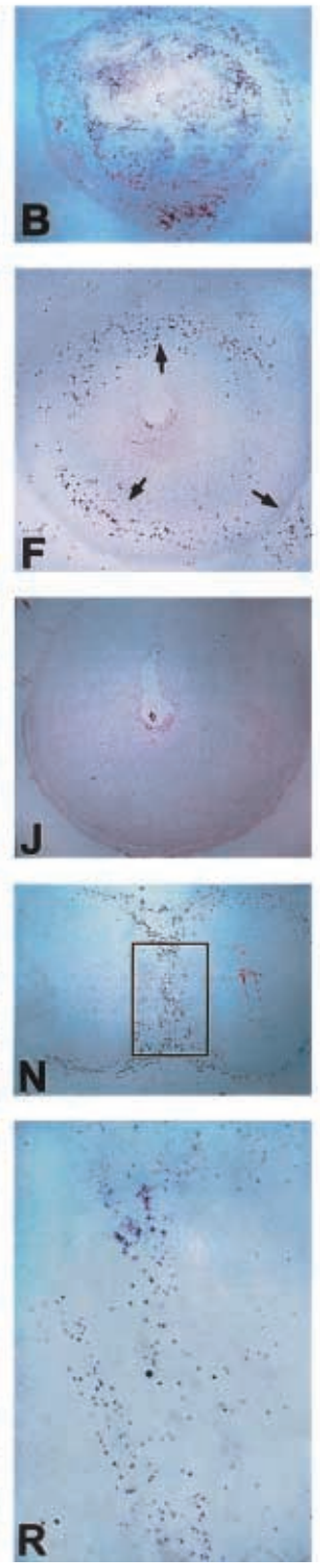

F4/80
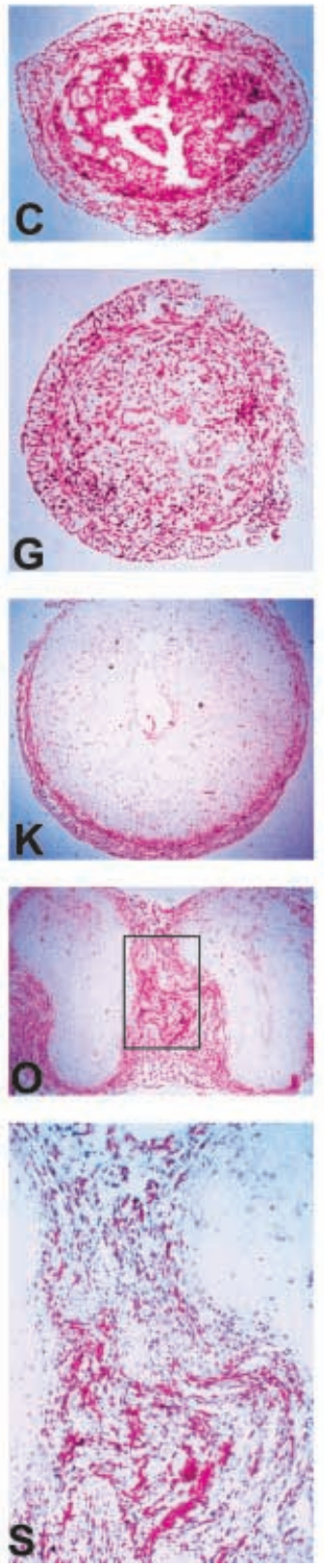

Anti-d/tPRP
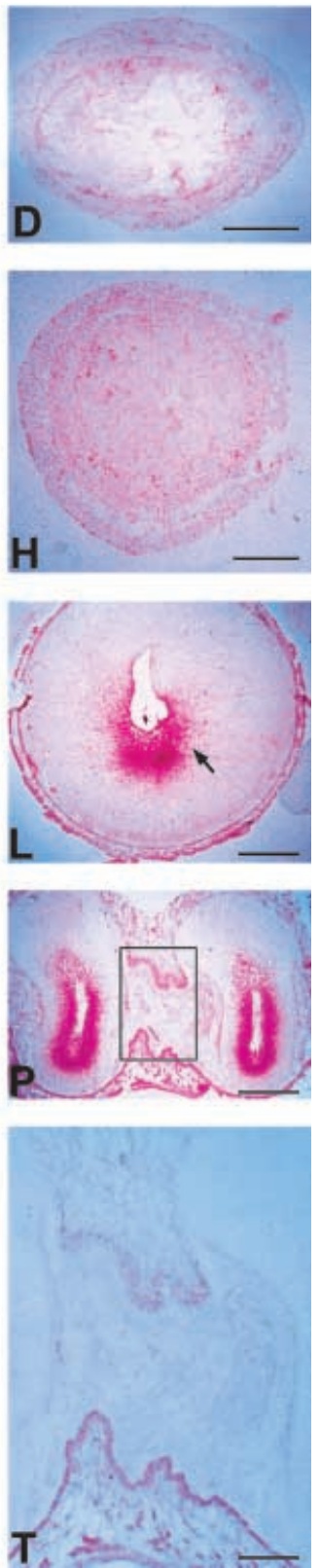

Figure 5 Comparison of AP-d/tPRP binding, eosinophil distribution, F4/80 antigen distribution, and d/tPRP expresssion in uterine tissues from non-pregnant (NP), day 4 pseudopregnant (PsD4), day 7 pseudopregnant (PsD7), and day 7 pregnant (PrD7) mice. AP-d/tPRP binding was detected by AP histochemistry following a postincubation with heparin $(A, E, I, M$ and Q). Eosinophil distribution was detected by histochemistry for eosinophil peroxidase (EPO; B, F, J, N, and R). F4/80 antigen distribution was detected by immunocytochemistry (C, G, K, O and S). D/tPRP expression was monitored by immunocytochemistry with polyclonal antibodies to rat d/tPRP (D, H, L, P and T). (A-D) Uterine sections from a non-pregnant mouse; $(\mathrm{E}-\mathrm{H})$ uterine sections from a PsD4 mouse; $(\mathrm{I}-\mathrm{L})$ uterine sections from a PsD7 mouse with a deciduoma; (M-P) uterine sections containing two developing embryos and an interimplantation region; (Q-T) high magnification of the interimplantation segments shown in M-P. Note the abundance of AP- $d / t P R P$ binding in uteri from non-pregnant mice, the relative exclusion of $\mathrm{AP}-\mathrm{d} / \mathrm{tPRP}$ binding in decidua associated with pseudopregnant and pregnant mice, and the reciprocal distribution of $\mathrm{d} / \mathrm{tPRP}$ binding and $\mathrm{d} / \mathrm{tPRP}$ expression in uteri PrD7 mice. Scale bars in D and $\mathrm{H}$ represent $500 \mu \mathrm{m}$. A-H are photographed at the same magnification. Scale bars in L and P represent $1 \mathrm{~mm}$. I-P are photographed at the same magnification. Scale bar in T is $250 \mu \mathrm{m}$. Q-T are photographed at the same magnification. Arrows highlight the locations of the positive cells. 
EPO

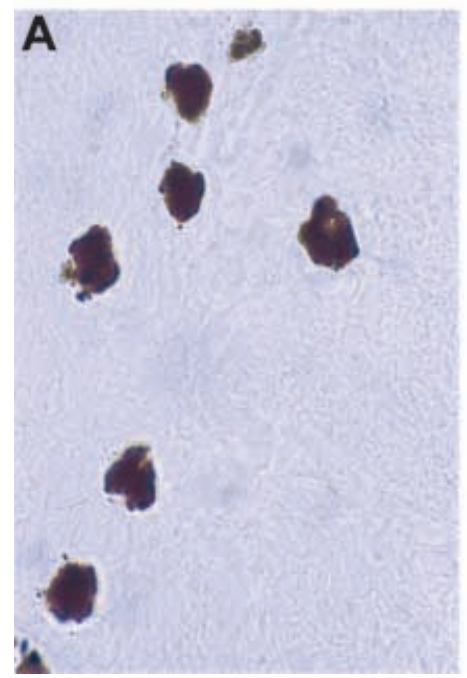

AP-d/tPRP

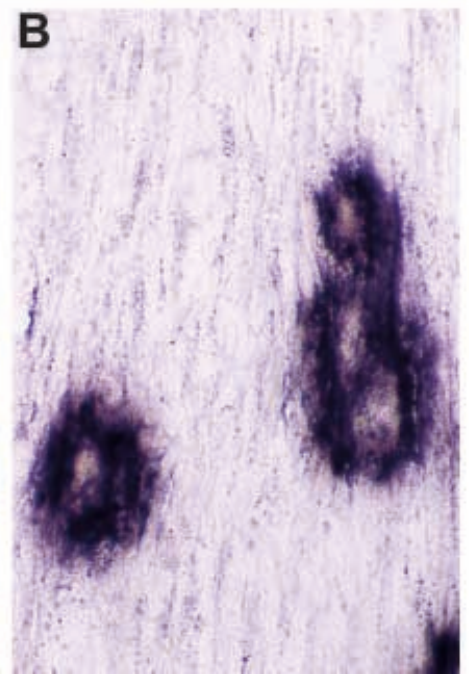

AP-d/tPRP+EPO

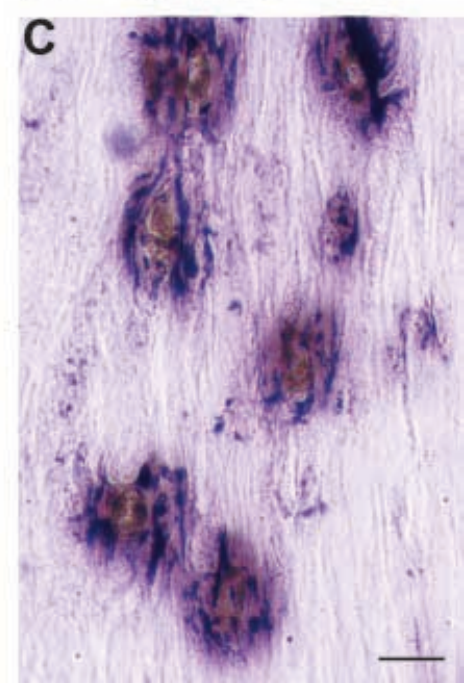

Figure 6 Co-localization of AP-d/tPRP binding and eosinophil peroxidase in mouse uterine eosinophils. Eosinophil peroxidase (EPO) was detected by histochemistry (A). AP-d/tPRP binding was detected by AP histochemistry following a postincubation with heparin (B). Dual localization of AP-d/tPRP binding and eosinophil peroxidase activity (C). Please note the 1:1 relationship between $A P-d / t P R P$ binding and eosinophil peroxidase activity. The length of the bar in $C$ is $10 \mu \mathrm{m}$.

$\mathrm{d} / \mathrm{tPRP}$ binding and eosinophils were virtually identical (Fig. 5). d/tPRP binding cells were most abundant in non-pregnant and day 4 pseudopregnant mouse endometrium and myometrium (Fig. 5A and E). Following the decidual reaction, $\mathrm{d} / \mathrm{tPRP}$ binding cells and eosinophils were rare within mouse decidua (Fig. 5I, J, M, N, Q and R). $d /$ tPRP binding was reciprocally related to the distribution of decidual cells expressing $d / t P R P$. Decidual cell patterns of $\mathrm{d} / \mathrm{tPRP}$ expression were similar to previous reports from our laboratory (Fig. $5 \mathrm{~L}$ and $\mathrm{P}$; Orwig et al. 1997a, Rasmussen et al. 1997). During pregnancy in the mouse, F4/80 positive cells, $\mathrm{d} / \mathrm{tPRP}$ binding cells and eosinophils were most prominent in interimplantation sites (Fig. 5Q, R and S). Furthermore, the number of F4/80 positive cells (macrophages +eosinophils) always outnumbered $d / t P R P$ binding cells, especially in tissues from pseudopregnant and pregnant mice. These observations were consistent with $\mathrm{d} / \mathrm{tPRP}$ interacting with eosinophils and/or a subpopulation of macrophages.

Identification of eosinophils as $\mathrm{d} / \mathrm{tPRP}$ targets The relationship between $\mathrm{d} / \mathrm{tPRP}$ binding cells, eosinophils and macrophages was further clarified by double labeling experiments. In addition, $\mathrm{AP}-\mathrm{d} / \mathrm{tPRP}$ binding to eosinophils and macrophages was examined using peritoneal cavity cells from the adult rat. Mouse uterine tissue sections dually processed for $\mathrm{d} / \mathrm{tPRP}$ binding and the localization of eosinophil peroxidase showed that $\mathrm{d} / \mathrm{tPRP}$ binding and eosinophil peroxidase co-localized (Fig. 6). In contrast, mouse uterine tissue sections dually processed for $\mathrm{d} / \mathrm{tPRP}$ binding and the immunolocalization of the F4/80 antigen showed that $\mathrm{d} / \mathrm{tPRP}$ bound to only a small subset of F4/80 positive cells (data not shown). This F4/80 positive subpopulation may correspond to cells of the monocyte-macrophage lineage or the eosinophil granulocyte lineage (McGarry \& Stewart 1991). Additional support for eosinophils as targets for $\mathrm{d} / \mathrm{tPRP}$ was demonstrated via the specific binding of $\mathrm{AP}-\mathrm{d} / \mathrm{tPRP}$ to eosinophils isolated from the peritoneum (Fig. 7) but not to macrophages isolated from the peritoneum (Fig. 7). Collectively, the results are consistent with $\mathrm{d} / \mathrm{tPRP}$ interacting with eosinophils.

The overall capacity of $\mathrm{d} / \mathrm{tPRP}$ binding to eosinophils present in the rat or mouse uterus (Figs 4 and 5) was consistently greater than observed for eosinophils isolated from the peritoneum (Fig. 7) or blood (data not shown). These observations prompted an investigation of $d / t$ PRP binding to eosinophils present in other tissues. $d / t P R P$ bound avidly to eosinophils present in the rat intestine and in the rat lung (Fig. 8). Thus, d/tPRP binding is not unique to uterine eosinophils and appears to be enhanced by eosinophils situated within tissues.

The specific association of $\mathrm{d} / \mathrm{tPRP}$ with tissue eosinophils was further demonstrated by examining AP-dPRP binding to tissues from normal and IL-5 transgenic mice (Lee et al. 1997b). IL-5 transgenic mice exhibit a generalized tissue eosinophilia. Uteri and lungs from prepubertal normal mice exhibit limited numbers of 


\section{AP-d/tPRP}

\section{EPO}

\section{WRIGHT}
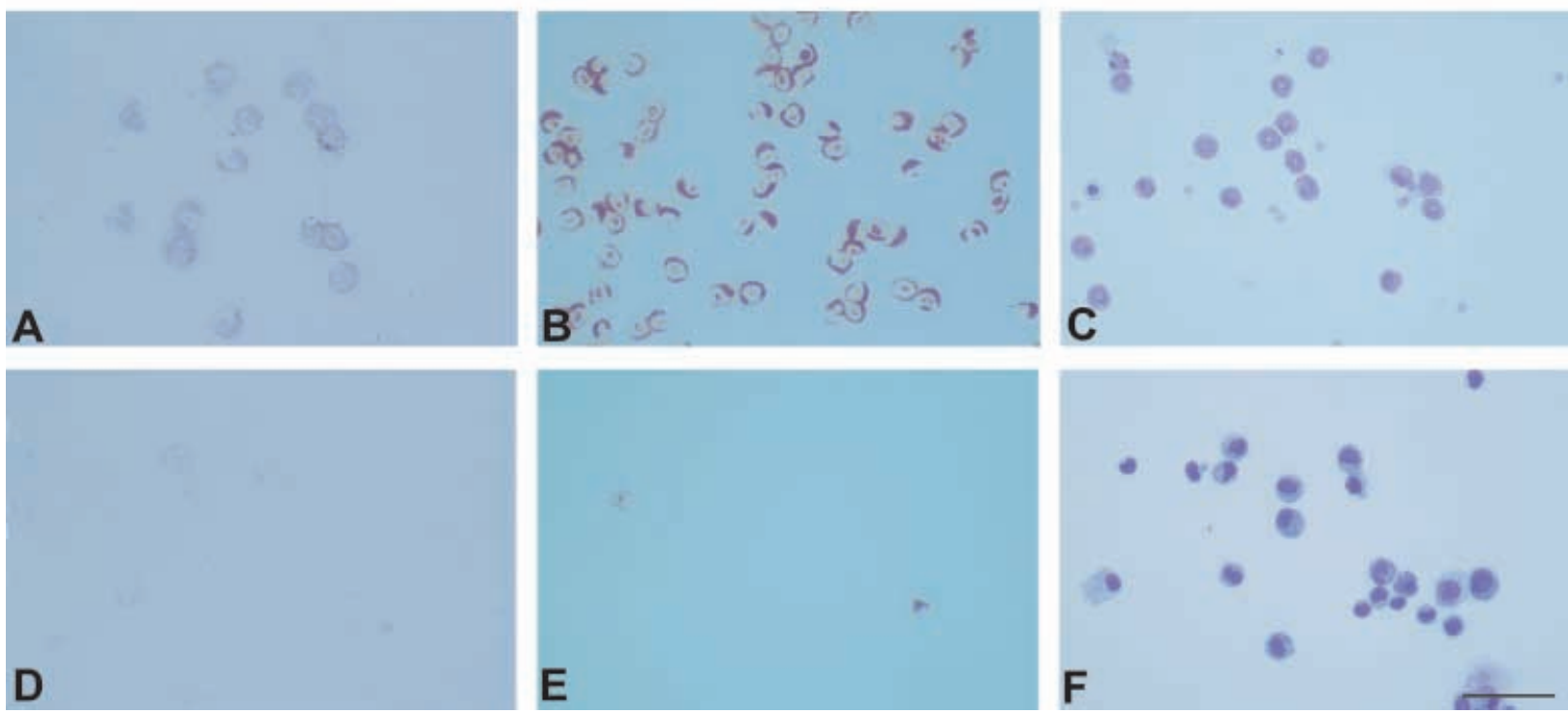

Figure 7 Binding of $\mathrm{AP}-\mathrm{d} / \mathrm{tPRP}$ to eosinophils versus macrophages. Eosinophils $(\mathrm{A}-\mathrm{C})$ and macrophages $(\mathrm{D}-\mathrm{F})$ were isolated from the rat peritoneum. $\mathrm{AP}-\mathrm{d} / \mathrm{tPRP}$ binding was detected by $\mathrm{AP}$ histochemistry following a postincubation with heparin (A and D). Eosinophils were detected by eosinophil peroxidase (EPO) histochemistry (B and E). Total cells in the peritoneal eosinophil or macrophage preparations were detected with Wright stain ( $\mathrm{C}$ and $\mathrm{F})$. AP- $\mathrm{d} / \mathrm{tPRP}$ bound to eosinophils but not macrophages. The length of the bar in F corresponds to $50 \mu \mathrm{m}$. All micrographs were photographed at the same magnification.

eosinophils and d/tPRP binding cells (Fig. 9A and B, E and F), whereas these same tissues from IL-5 transgenic mice show extensive numbers of eosinophils and $\mathrm{d} / \mathrm{tPRP}$ binding cells (Fig. 9C and D, G and $\mathrm{H}$ ).

\section{Estrogen control of uterine $\mathrm{d} / \mathrm{tPRP}$ binding and eosinophil distributions Eosinophils exhibit dynamic} changes within the uterus dependent upon the steroid hormone milieu. For example, estrogen stimulates the infiltration of eosinophils into the uterus (Bjersing \& Borglin 1964, King et al. 1981, Tchernitchin 1983, Lee et al. 1989). This observation was confirmed by administration of exogenous estradiol (Fig. 10). Cells binding $\mathrm{d} / \mathrm{tPRP}$ and possessing eosinophil peroxidase dramatically increased in uteri from the estradiol-treated versus the vehicle-treated control rats.

\section{Identification of $d / t P R P$ targets within the chorioallantoic placenta}

$\mathrm{d} / \mathrm{tPRP}$ is characterized by its dual expression in decidual tissue from implantation until mid-gestation and in spongiotrophoblast and trophoblast giant cells of the chorioallantoic placenta from mid-gestation until the end of pregnancy (Orwig et al. 1997a,b; Rasmussen et al. 1997). $\mathrm{AP}-\mathrm{d} / \mathrm{tPRP}$ binding was examined in mouse and rat uteroplacental tissues from mid-pregnancy to term. $\mathrm{AP}-\mathrm{d} / \mathrm{tPRP}$ bound specifically and prominently to the labyrinth zone of mouse (Fig. 11) and rat (data not shown) chorioallantoic placentas. $\mathrm{d} / \mathrm{tPRP}$ binding appeared to increase as a function of gestational development.

\section{Discussion}

\section{$d / t P R P$ interactions with heparin-containing molecules}

Heparin-containing molecules are prominently displayed on the external surfaces of cells and their extracellular matrices (Hassell et al. 1986). Several pieces of data are consistent with $d /$ tPRP interactions with heparincontaining molecules: i) $\mathrm{d} / \mathrm{tPRP}$ specifically binds to heparin Sepharose and is released from cultured cells by treatment with heparitinase (Rasmussen et al. 1996); ii) $\mathrm{d} / \mathrm{tPRP}$ co-isolates with extracellular matrix proteins and is not detectable in maternal circulation (Rasmussen et al. 1996); iii) $d /$ tPRP binds to wild-type heparan sulfatecontaining $\mathrm{CHO}$ cells but not to heparan sulfate-deficient CHO-pgsD-677 cells (present study); iv) d/tPRP binding to tissues is dramatically affected by pretreatment with heparitinase and/or heparin (present study). d/tPRPheparin interactions are likely relevant to the actions of $\mathrm{d} / \mathrm{tPRP}$ on its targets. These ligand-heparin associations presumably facilitate the accumulation of $d / t P R P$ in proximal locations and prevent $\mathrm{d} / \mathrm{tPRP}$ from accessing systemic targets. $\mathrm{d} / \mathrm{tPRP}$ interactions with heparin may also contribute conformationally to the biological 


\section{AP-d/tPRP}
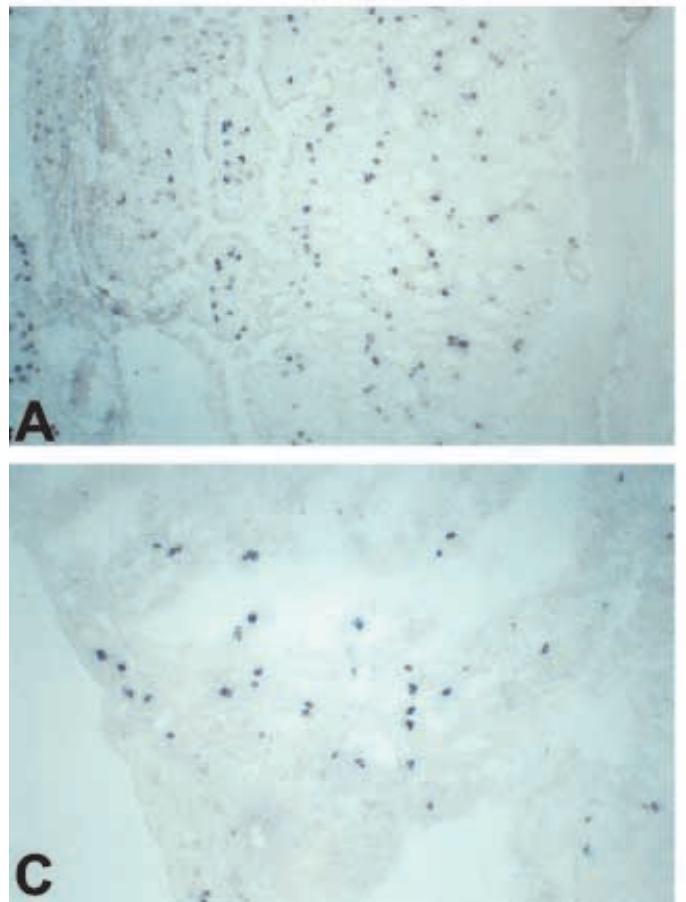

\section{EPO}
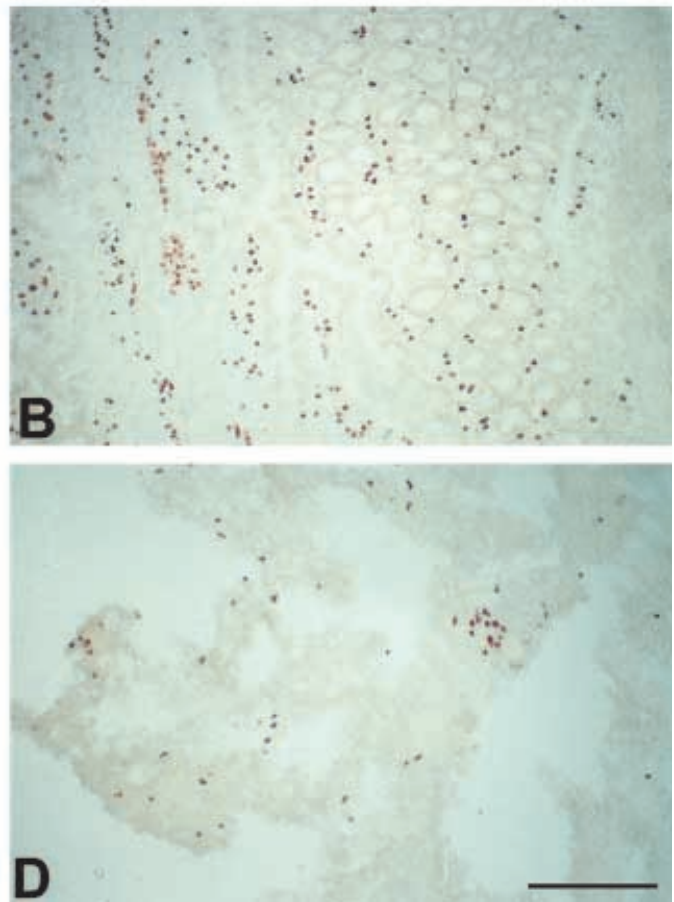

Figure $8 \mathrm{AP}-\mathrm{d} / \mathrm{tPRP}$ binding and eosinophils distributions in rat intestinal $(\mathrm{A}$ and $\mathrm{B})$ and rat lung tissues $(\mathrm{C}$ and D). AP-d/tPRP binding was detected by AP histochemistry following a postincubation with heparin (A and C). Eosinophils were detected by eosinophil peroxidase (EPO) histochemistry (B and D). The length of the bar in D corresponds to $200 \mu \mathrm{m}$. All micrographs were photographed at the same magnification.

activation of $d / t P R P$ and/or the prevention of $d / t P R P$ degradation.

Diffusion of $\mathrm{d} / \mathrm{tPRP}$ away from its cellular sources within decidua versus the chorioallanotic placenta likely differ due to differences in the heparan sulfate composition of the two sites. Extracellular matrix of the decidua is richly endowed in heparan sulfate proteoglycans (Wewer et al. 1986), whereas the junctional zone of the
AP-d/tPRP

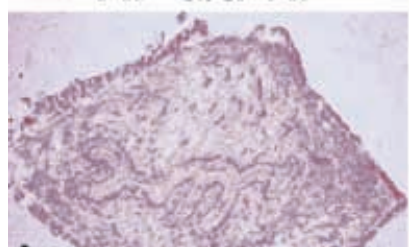

A

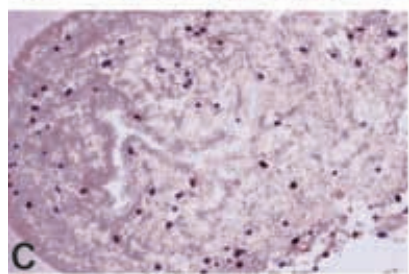

EPO
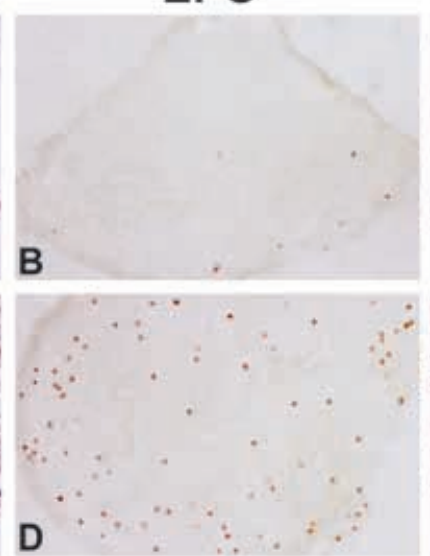

AP-d/tPRP

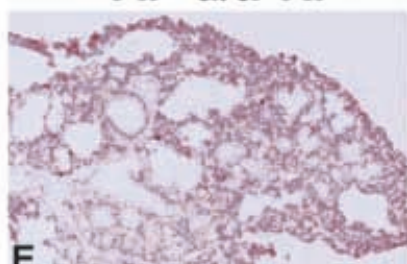

E

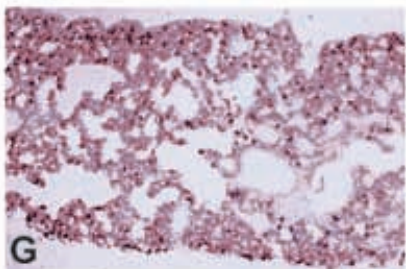

EPO

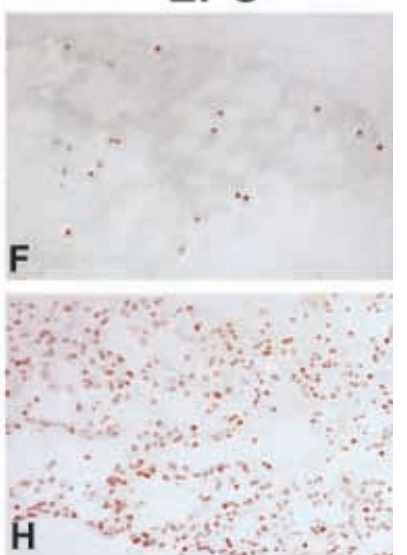

Figure $9 \mathrm{AP}-\mathrm{d} / \mathrm{tPRP}$ binding and eosinophil distributions in tissues from normal (A and $\mathrm{B} ; \mathrm{E}$ and $\mathrm{F}$ ) and IL-5 transgenic mice (C and D; $\mathrm{G}$ and $\mathrm{H})$. Analyses were performed on uterine $(\mathrm{A}-\mathrm{D})$ and lung $(\mathrm{E}-\mathrm{G})$ tissues from prepubertal female mice. AP- $\mathrm{d} / \mathrm{tPRP}$ binding was detected by AP histochemistry following a postincubation with heparin (A, C, E and G). Eosinophils were detected by eosinophil peroxidase (EPO) histochemistry $(B, D, F$ and $H)$. All micrographs were photographed at the same magnification. 


\section{AP-d/tPRP}

\section{EPO}

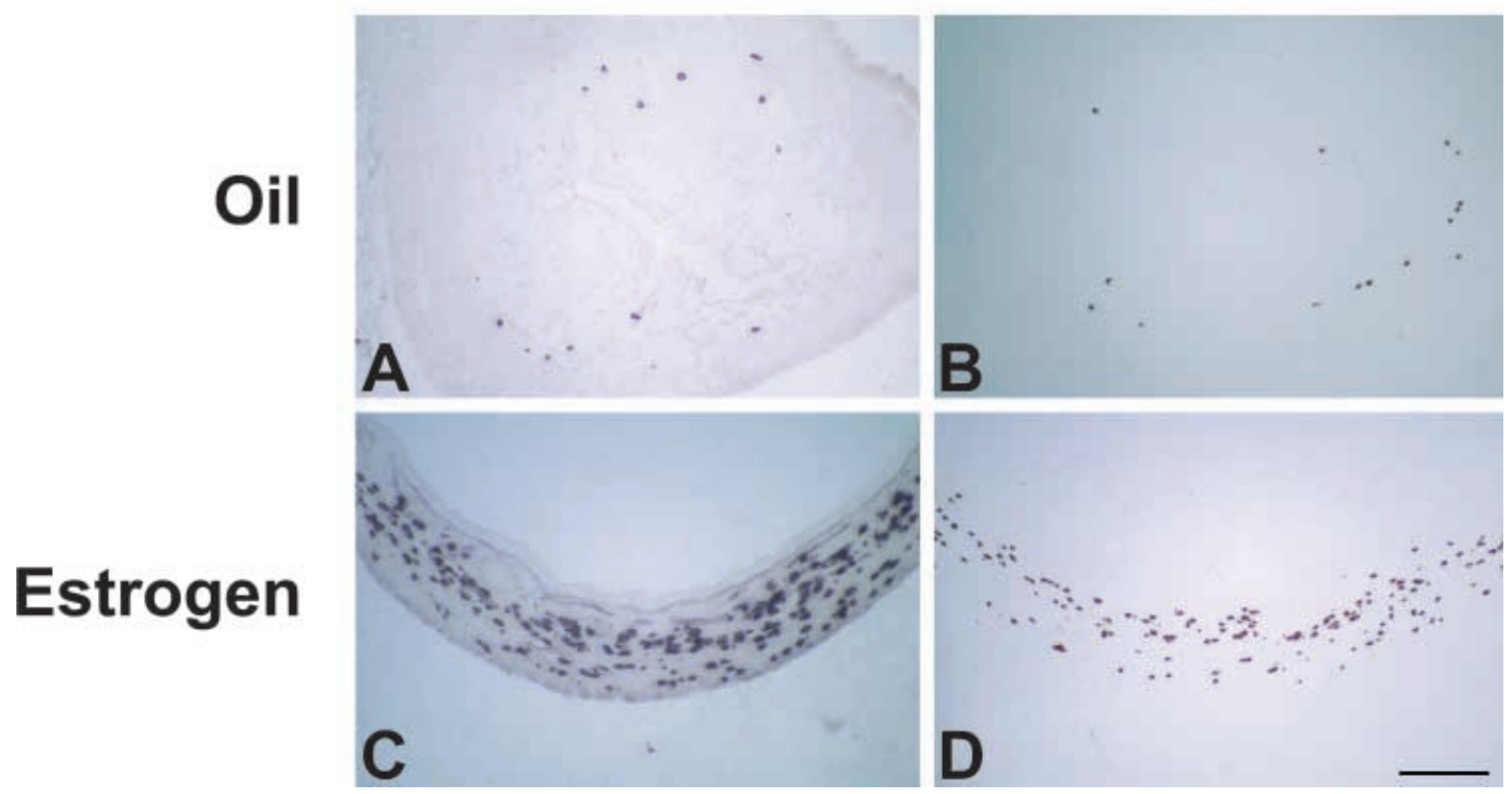

Figure 10 Estrogen control of uterine d/tPRP binding and eosinophil distributions. Prepubertal rats (day 20 postnatal) were subcutaneously injected daily for 3 days with estradiol valerate $(100 \mu \mathrm{g} / 100 \mu \mathrm{l}$; A and B) or vehicle (sesame oil; C and D). Twenty-four hours following the last injection, rats were killed, uterine tissues dissected and frozen for subsequent analysis. $\mathrm{AP}-\mathrm{d} / \mathrm{tPRP}$ binding was detected by AP histochemistry following a postincubation with heparin (A and C). Eosinophils were detected by eosinophil peroxidase histochemistry (B and D). The length of the bar in D corresponds to $100 \mu \mathrm{m}$. All micrographs were photographed at the same magnification.

chorioallantoic placenta is conspicuously devoid of heparan sulfate proteoglycans (Laurie 1985). This dichotomy in the environment surrounding the sites of $\mathrm{d} / \mathrm{tPRP}$ synthesis presumably results in differential access to targets within these tissues. During the first half of pregnancy, d/tPRP

\section{Mouse Placenta (D16)}

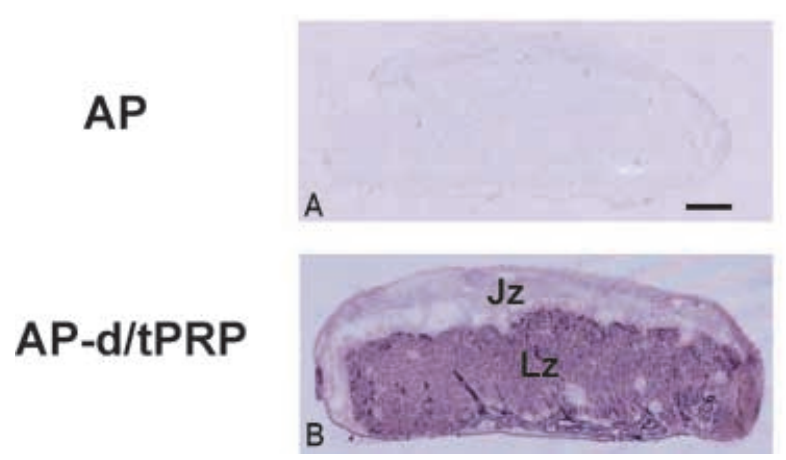

Figure $11 \mathrm{AP}-\mathrm{d} / \mathrm{tPRP}$ binding to the mouse chorioallantoic placenta isolated from gestation day 16 . AP-d/tPRP binding was detected by AP histochemistry following a postincubation with heparin. (A) AP control; (B) AP-d/tPRP. Please note that AP-d/tPRP specifically bound to the labyrinth zone of the chorioallantoic placenta. The length of the bar in A represents $500 \mu \mathrm{m}$. diffusion is likely restricted to the decidual cells responsible for its synthesis and the associated extracellular matrix, whereas during the second half of gestation, $d / t P R P$ is likely capable of diffusing to tissues bordering the junctional zone, i.e. decidual basalis and labyrinth zone of the chorioallantoic placenta.

\section{$d / t P R P$ interactions with eosinophils}

Eosinophils are components of inflammatory responses that are likely to participate in immune surveillance against parasitic infections and solid tumors (Gleich et al. 1993, Venge 1993, Weller 1993, Tepper et al. 1992, Tepper 1994, Hirai et al. 1997, Rothenberg 1998, Giembycz \& Lindsay 1999, LeMoine et al. 1999a,b). These cells are identified based on the composition of their granules which contain a variety of cytotoxic molecules that can cause considerable damage to surrounding normal cells (Gleich et al. 1993, Venge 1993, Weller 1993, Hirai et al. 1997, Rothenberg 1998, Giembycz \& Lindsay 1999).

Eosinophils are normal, and relatively abundant, constituents of both rodent and human uterine endometria (Rytomaa 1960, Bassett 1962, Ross \& Klebanoff 1966, McMaster et al. 1992, Jeziorska et al. 1995). In rodents, the most dramatic changes in uterine eosinophil distributions 
occur prior to mating and during pregnancy. Eosinophils infiltrate into the uterine endometrium preceding mating and are effectively removed from the vicinity of the developing embryo accompanying the establishment of pregnancy (McMaster et al. 1992, present study). It may be advantageous to have eosinophils present in the uterus around the time of mating when there is a possibility for the introduction of potential infectious agents. Likewise, it would also appear efficacious to remove or restrain the eosinophils once the pregnancy has been initiated in order to prevent their attack of the semi-allogeneic embryo. Mechanisms underlying this form of immunoprotection have not been well defined. Decidual tissue represents a barrier effectively excluding eosinophils (present study). Progesterone participates in the control of the development of decidual cells (DeFeo 1967, Lydon et al. 1995) and possesses key anti-inflammatory actions within the uterus (Siiteri \& Stites 1982, Finn 1986, Tibbetts et al. 1999). d/tPRP likely contributes to the maternal adaptation to pregnancy and may mediate, at least in part, the anti-inflammatory actions of progesterone. Once secreted, $\mathrm{d} / \mathrm{tPRP}$ is trapped in the decidual extracellular matrix where it associates with heparin-containing molecules and has access to migratory cells, including eosinophils (Rasmussen et al. 1996, present study). Intracellular pathways activated by $\mathrm{d} / \mathrm{tPRP}$ may culminate in the protection of the developing embryo from the potentially cytotoxic actions of eosinophils. In this hypothesis, alteration of eosinophil activities facilitates survival of genetically disparate extraembryonic and embryonic tissues. $\mathrm{d} / \mathrm{tPRP}$ is capable of interacting with eosinophils located in uterine and extrauterine tissues (present study) and with eosinophils from other species (including guinea pig, dog and cow; D Wang, D Walia \& M J Soares, unpublished results). Systemic effects of $\mathrm{d} / \mathrm{tPRP}$ on extrauterine eosinophils are likely obviated by the association of $\mathrm{d} / \mathrm{tPRP}$ with heparin-containing molecules on the cell surface and within the extracellular matrix.

\section{$d / t P R P$ interactions with the labyrinthine placental compartment}

As gestation progresses, $\mathrm{d} / \mathrm{tPRP}$ is produced in the junctional zone of the chorioallantoic placenta (Rasmussen et al. 1997), where it presumably diffuses to adjoining tissues due to the absence of heparan sulfate proteoglycan within the junctional zone (Laurie 1985). This secreted $\mathrm{d} /$ tPRP may potentially target the underlying labyrinthine trophoblast and eosinophils in the decidual basalis (present study).

\section{Overview}

$\mathrm{d} / \mathrm{tPRP}$ is part of a larger family of regulatory molecules that help ensure viviparity. This family includes: PRL, which possesses specific modulatory actions on the maternal ovaries, liver, and mammary gland (Soares et al. 1998); proliferin and proliferin-related protein, which influence development of vasculature within the uteroplacental compartment (Jackson et al. 1994); PRL-like protein-A, which specifically targets uterine natural killer cells (Müller et al. 1999); and PRL-like protein-E, which controls aspects of hematopoiesis (Lin \& Linzer 1999). The biology of other members of the uteroplacental PRL family are yet to be described.

The nature of $d /$ tPRP's actions on eosinophils or the labyrinthine placenta is not known. d/tPRP does not interact with the PRL receptor (Rasmussen et al. 1996, present study). Consequently, d/tPRP actions are likely mediated by alternative signaling pathways. It is not entirely clear whether specific and unique receptor signaling systems have co-evolved with each PRL family member, whether PRL family members utilize signaling pathways for other known ligands, or whether PRL family members act through receptor-independent mechanisms (e.g. transport proteins, binding proteins, etc.).

In summary, using an AP tagging strategy, $d / t P R P$ is shown to specifically interact with eosinophils and the labyrinthine placenta. We propose that $\mathrm{d} / \mathrm{tPRP}$ participates in the regulation of uterine eosinophils and the labyrinthine placenta in ways that contribute to the establishment and maintenance of pregnancy.

\section{Acknowledgements}

This work was supported by grants from the National Institute of Child Health and Human Development (HD02528, HD29797, HD33994 to M J S), the National Heart, Lung, and Blood Institute (HL58723, to N A L), the J B Reynolds Foundation (to M J S), and the Mayo Foundation (to J J L and N A L). We thank Drs Paul Kelly, Stephen Russell, and M J Dembele-Duchesne for the PRL receptor expression vector, F4/80 monoclonal antibody, and antibodies to rat major basic protein. We would like to thank Patrick Moonsaar and Donald Warn for assistance with the preparation of some of the graphic materials.

D Wang is supported by a fellowship from the Kansas Health Foundation. R Ishimura is supported by a fellowship from the Japan Society for the Promotion of Science. H Müller is supported by a fellowship from the Deutsche Forschungsgemeinschaft of Germany (Mu1183/1-1). N A Lee is supported by the Mayo Foundation.

\section{References}

Ali S, Edery M, Pellegrin I, Lesueur L, Paly J, Djiane J \& Kelly PA $1992 \mathrm{The} \mathrm{Nb} 2$ form of prolactin receptor is able to activate a milk protein gene promoter. Molecular Endocrinology 6 1242-1248.

Austyn JM \& Gordon S 1981 F4/80: a monoclonal antibody directed specifically against the mouse macrophage. European Journal of Immunology 11 805-811. 
Bassett EG 1962 Infiltration of eosinophils into the modified connective tissue of oestrous and pregnant animals. Nature 194 1259-1261.

Bell SC 1983 Decidualization: regional differentiation and associated function. Oxford Review of Reproductive Biology 5 220-271.

Berger J, Hauber J, Hauber R, Geiger R \& Cullen BR 1988 Secreted placental alkaline phosphatase: a powerful new quantitative indicator of gene expression in eukaryotic cells. Gene 66 101-106.

Bjersing L \& Borglin NE 1964 Effect of hormones on incidence of uterine eosinophilia in rats. Acta Pathologica Microbiologica Scandinavica $60353-364$.

Brandon JM 1993 Leucocyte distribution in the uterus during the preimplantation period of pregnancy and phagocyte recruitment to sites of blastocyst attachment in mice. Journal of Reproduction and Fertility 98 567-576.

Brandon JM 1995 Macrophage distribution in decidual tissue from early implantation to the periparturient period in mice as defined by the macrophage differentiation antigens F4/80, macrosialin and the type 3 complement receptor. Journal of Reproduction and Fertility 103 9-16.

Deb S, Hamlin GP, Roby KF, Kwok SCM \& Soares MJ 1993 Heterologous expression and characterization of prolactin-like protein-A: identification of serum binding proteins. Journal of Biological Chemistry 268 3298-3305.

DeFeo VJ 1967 Decidualization. In Cellular Biology of the Uterus, pp 191-290. Ed. RM Wynn. New York: Appleton-Century-Crofts.

Dembele-Duchesne M-J, Badia E, Etienne-Julan M \& Capony J-P 1991 Identification and tissue localization of an eosinophil $17 \mathrm{kDa}$ protein accumulating in rat uterus upon estradiol treatment. Journal of Steroid Biochemistry and Molecular Biology 38 321-330.

Dijkstra CD, Dopp EA, Joling P \& Kraal G 1985 The heterogeneity of mononuclear phagocytes in lymphoid organs: distinct macrophage subpopulations in the rat recognized by monoclonal antibodies ED1, ED2, and ED3. Immunology 54 589-599.

Dileepan KN, Lorsbach RB \& Stechschulte DJ 1993 Mast cell granules inhibit macrophage-mediated lysis of mastocytoma cells (P815) and nitric oxide production. Journal of Lenkocyte Biology $\mathbf{5 3}$ 446-453.

Enders AC \& Welsh AO 1993 Structural interactions of trophoblast and uterus during hemochorial placenta formation. Journal of Experimental Zoology 266 578-587.

Finn CA 1986 Implantation, menstruation and inflammation. Biological Reviews 61 313-328.

Giembycz MA \& Lindsay MA 1999 Pharmacology of the eosinophil. Pharmacological Reviews 51 213-339.

Gleich GJ, Adolphson CR \& Leiferman KM 1993 The biology of the eosinophilic leukocyte. Annual Review of Medicine 44 85-101.

Gu Y, Soares MJ, Srivastava RK \& Gibori G 1994 Expression of decidual prolactin-related protein in the rat decidua. Endocrinology $1351422-1427$.

Hassell JR, Kimura JH \& Hascall VC 1986 Proteoglycan core protein families. Annual Review of Biochemistry 55 539-567.

Hirai K, Miyamasu M, Takaishi T \& Morita Y 1997 Regulation of the function of eosinophils and basophils. Critical Reviews in Immunology 17 325-352.

Horton MA, Larson KA, Lee JJ \& Lee NA 1996 Cloning of the murine eosinophil peroxidase gene $(\mathrm{mEPO})$ : characterization of a conserved subgroup of mammalian hematopoietic peroxidases. Journal of Leukocyte Biology 60 285-294.

Howe RS, Lee YH, Fischokoff SA, Teuscher C \& Lyttle CR 1990 Glucocorticoid and progestin regulation of eosinophil chemotactic factor and complement $\mathrm{C} 3$ in the estrogen-treated rat uterus. Endocrinology 126 3193-3199.

Jackson D, Volpert OV, Bouck N \& Linzer DIH 1994 Stimulation and inhibition of angiogenesis by placental proliferin and proliferinrelated protein. Science 266 1581-1584.
Jeziorska M, Salamonsen LA \& Woolley DE 1995 Mast cell and eosinophil distribution and activation in human endometrium throughout the menstrual cycle. Biology of Reproduction 53 312-320.

Kaushic K, Frauendorf E, Rossoll RM, Richardson JM \& Wira CR 1998 Influence of the estrous cycle on the presence and distribution of immune cells in the rat reproductive tract. American Journal of Reproductive Immunology 39 209-216.

Kay AB, Barata L, Meng Q, Durham SR \& Ying S 1997 Eosinophils and eosinophil-associated cytokines in allergic inflammation. International Archives of Allergy and Immunology 113 196-199.

King WJ, Allen TC \& DeSombre ER 1981 Localization of uterine peroxidase activity in estrogen-treated rats. Biology of Reproduction $\mathbf{2 5}$ 859-870.

Laurie GW 1985 Lack of heparan sulfate proteoglycan in a discontinuous and irregular placental basement membrane. Developmental Biology 108 299-309.

Lee JJ, McGarry MP, Farmer SC, Denzler KL, Larson KA, Carrigan PE, Brenneise IE, Horton MA, Haczdu A, Gelfand EW, Leikauf GD \& Lee NA 1997a Interleukin-5 expression in the lung epithelium of transgenic mice leads to pulmonary changes pathognomonic of asthma. Journal of Experimental Medicine 185 2143-2156.

Lee NA, McGarry MP, Larson KA, Horton MA, Kristensen AB \& Lee JJ $1997 b$ Expression of IL-5 in thymocytes/T cells leads to the development of massive eosinophilia, extramedullary eosinophilopoiesis, and unique histopathologies. Journal of Immunology 158 1332-1344.

Lee YH, Howe RS, Sha S-J, Teuscher C, Sheehan DM \& Lyttle CR 1989 Estrogen regulation of an eosinophil chemotactic factor in the immature rat uterus. Endocrinology 125 3022-3028.

Le Moine A, Flamand V, Demoor F-X, Noel J-C, Surquin M, Kiss R, Nahori M-A, Pretolani M, Goldman M \& Abramowicz D 1999 a Critical roles for IL-4, IL-5, and eosinophils in chronic skin allograft rejection. Journal of Clinical Investigation 103 1659-1667.

Le Moine A, Surquin M, Demoor F-X, Noel JC, Nahori M-A, Pretolani M, Flamand V, Braun MY, Goldman M \& Abramowicz D $1999 b$ IL-5 mediates eosinophilic rejection of MHC class II-disparate skin allografts in mice. Journal of Immunology 163 3778-3784.

Lidholt K, Weinke JL, Kiser CS, Lugenwa FN, Bame KJ, Cheifetz S, Massague J, Lindhahl U \& Esko JD 1992 A single mutation affects both $\mathrm{N}$-acetylglucosaminyltransferase and glucuronosyltransferase activities in a Chinese hamster ovary cell mutant defective in heparan sulfate biosynthesis. PNAS 89 2267-2271.

Lin J \& Linzer DIH 1999 Induction of megakaryocyte differentiation by a novel pregnancy-specific hormone. Journal of Biological Chemistry 274 21485-21489.

Lin J, Poole J \& Linzer DIH 1997 Three new members of the mouse prolactin/growth hormone family are homologous to proteins expressed in the rat. Endocrinology 138 5541-5549.

Lydon JP, DeMayo FJ, Funk CR, Mani SK, Hughes AR, Montgomery CA, Shyamala G, Conneely OM \& O'Malley BW 1995 Mice lacking progesterone receptor exhibit pleiotropic reproductive abnormalities. Genes and Development $92266-2278$.

McGarry MP \& Stewart CC 1991 Murine eosinophil granulocytes bind the murine macrophage-monocyte specific monoclonal antibody F4/80. Journal of Leukocyte Biology 50 471-478.

MacKenzie CD, Jungery M, Taylor PM \& Ogilvie BM 1981 The in vitro interaction of eosinophils, neutrophils, macrophages and mast cells with nematode surfaces in the presence of complement or antibodies. Journal of Pathology 133 161-175.

McMaster MT, Newton RC, Dey SK \& Andrews GK 1992 Activation and distribution of inflammatory cells in the mouse uterus during the preimplantation period. Journal of Immunology 148 $1699-1705$.

Müller H, Dai G \& Soares MJ 1998 Placental lactogen-I (PL-I) target tissues identified with an alkaline phosphatase-PL-I fusion protein. Journal of Histochemistry and Cytochemistry 46 737-744. 
Müller H, Liu B, Croy BA, Head JR, Dai G \& Soares MJ 1999 Uterine natural killer cells are targets for a trophoblast cell-specific cytokine, prolactin-like protein-A. Endocrinology 140 2711-2720.

Orwig KE, Dai G, Rasmussen CA \& Soares MJ 1997a Decidual/ trophoblast prolactin related protein: characterization of gene structure and cell-specific expression. Endocrinology 138 2491-2500.

Orwig KE, Ishimura R, Müller H, Liu B \& Soares MJ 1997 b Identification and characterization of a mouse homolog for decidual/trophoblast prolactin-related protein. Endocrinology 139 $5511-5517$.

Parr MB \& Parr EL 1989 The implantation reaction. In Biology of the Uterus, pp 233-278. Eds RM Wynn \& WP Jollie. New York: Plenum.

Pearlman E 1997 Immunopathology of onchocerciasis: a role for eosinophils in onchocercal dermatitis and keratitis. Chemical Immunology 66 26-40.

Rasmussen CA, Hashizume K, Orwig KE, Xu L \& Soares MJ 1996 Decidual prolactin-related protein: heterologous expression and characterization. Endocrinology 137 5558-5566.

Rasmussen CA, Orwig KE, Vellucci S \& Soares MJ 1997 Dual expression of prolactin-related protein in decidua and trophoblast tissues during pregnancy. Biology of Reproduction 55 647-654.

Redline RW \& Lu CY 1989 Localization of fetal major histocompatibility complex antigens and maternal leukocytes in murine placenta. Laboratory Investigation 61 27-36.

Roby KF, Deb S, Gibori G, Szpirer C, Levan G, Kwok SCM \& Soares MJ 1993 Decidual prolactin-related protein: identification, molecular cloning, and characterization. Journal of Biological Chemistry 268 3136-3142.

Ross R \& Klebanoff SJ 1966 The eosinophilic leukocyte. Fine structure studies of changes in the uterus during the estrous cycle. Journal of Experimental Medicine 124 653-659.

Rothenberg ME 1998 Eosinophilia. New England Journal of Medicine 338 1592-1600.

Rytomaa T 1960 Organ distribution and histochemical properties of eosinophil granulocytes in rat. Acta Pathologica Microbiologica Scandinavica (Suppl) 140 11-118.

Siiteri P \& Stites DP 1982 Immunologic and endocrine interrelationships in pregnancy. Biology of Reproduction 26 1-14.

Soares MJ 1987 Developmental changes in the intraplacental distribution of placental lactogen and alkaline phosphatase in the rat. Journal of Reproduction and Fertility 79 93-98.

Soares MJ, Colosi P, Ogren L \& Talamantes F 1983 Identification and partial characterization of a lactogen from the midpregnant mouse conceptus. Endocrinology 112 1313-1317.

Soares MJ, Dai G, Orwig KE, Peters TJ \& Müller H 1998 The uteroplacental prolactin family and pregnancy. Biology of Reproduction $\mathbf{5 8} 273-284$.
Stewart IJ \& Mitchell BS 1991 The distribution of uterine macrophages in virgin and early pregnant mice. Journal of Anatomy 179 183-196.

Stewart IJ \& Mitchell BS 1992 Macrophages and other endocytic cells in the mouse uterus during the second half of pregnancy and into the postpartum period. Journal of Anatomy 181 119-126.

Tachi C \& Tachi S 1986 Macrophages and implantation. Annals of the New York Academy of Sciences 476 158-182.

Tachi C \& Tachi S 1989 Role of macrophages in the maternal recognition of pregnancy. Journal of Reproduction and Fertility 37 63-68.

Tanaka T, Shiu RPC, Gout PW, Beer CT, Noble RL \& Friesen HG 1980 A new sensitive and specific bioassay for lactogenic hormones: measurement of prolactin and growth hormone in human serum. Journal of Clinical Endocrinology and Metabolism 51 1058-1062.

Tchernitchin AN 1983 Eosinophil-mediated non-genomic parameters of estrogen stimulation - a separate group of responses mediated by an independent mechanism. Journal of Steroid Biochemistry 19 95-100.

Tepper RI 1994 The eosinophil-mediated antitumor activity of interleukin-4. Journal of Allergy and Clinical Immunology $\mathbf{9 4}$ 1225-1231.

Tepper RI, Coffman RL \& Leder P 1992 An eosinophil-dependent mechanism for the antitumor effect of interleukin-4. Science 257 $548-551$.

Tibbetts TA, Conneely OM \& O’Malley BW 1999 Progesterone via its receptor antagonizes the pro-inflammatory activity of estrogen in the mouse uterus. Biology of Reproduction 60 1158-1165.

Venge P 1993 Human eosinophil granule proteins: structure, function, and release. In Immunopharmacology of eosinophils, pp 43-56. Eds H Smith \& RM Cook. New York: Academic Press.

Weller PF 1993 Lipid, peptide, and cytokine mediators elaborated by eosinophils. In Immunopharmacology of eosinophils, pp 25-42. Eds H Smith \& RM Cook. New York: Academic Press.

Wewer UM, Damjanov A, Weiss J, Liotta LA \& Damjanov I 1986 Mouse endometrial stromal cells produce basement-membrane components. Differentiation 32 49-58.

Yelavarthi KK, Chen H-L, Yang Y, Cowley BD, Fishback JL \& Hunt JS 1991 Tumor necrosis factor-alpha mRNA and protein in rat uterine and placental cells. Journal of Immunology 146 $3840-3848$.

Received 29 February 2000

Accepted 5 June 2000 